\title{
Free Carnitine Measurement
}

National Cancer Institute

\section{Source}

National Cancer Institute. Free Carnitine Measurement. NCI Thesaurus. Code C74677.

The determination of the amount of free carnitine present in a sample. 